\title{
PENERAPAN TEORI PEMBIASAAN DALAM PEMBENTUKAN KARAKTER RELIGI SISWA DI TINGKAT SEKOLAH DASAR
}

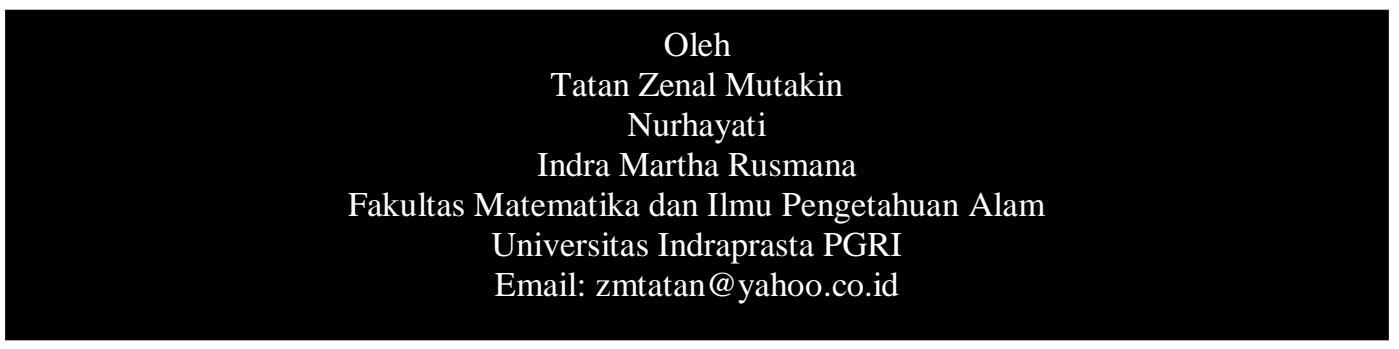

Abstract, This study aims to determine the extent of the application of a religious character education through habituation theory in State Primary School in South Tangerang City area. This study is part of Research and Development held in several elementary schools in South Tangerang to implement character education through religious activities. During the 6 month study period, ie April-August 2014.

The study concluded that: 1) Implementation of the religious dimension through habituation five daily prayers and recitation of the Qur'an can only be carried out by the students in the life of $36,82 \%, 2)$ of the whole school who were respondents in this study, the majority has not can implement character education process for the dimensions religus with habituation method, 3) after the treatment method of habituation, the implementation of the five daily prayers and recitation of the verses of Qur'an has increased significantly; from $36,82 \%$ to $57,13 \%$, although the implementation of the five daily prayers can be conducted in a timely yet by the students.

Keywords: Character Education, Religious Activity

Abstrak, Penelitian ini bertujuan untuk mengetahui sejauhmana penerapan pendidikan karakter religi melalui teori pembiasaan di Sekolah Dasar Negeri yang ada di wilayah Kota Tangerang Selatan. Penelitian ini merupakan bagian dari penelitian riset dan pengembangan (Research and Development) yang dilaksanakan di beberapa Sekolah Dasar di Kota Tangerang Selatan dengan menerapkan pendidikan karakter melalui kegiatan religi. Waktu penelitian selama 6 bulan, yaitu bulan April- Agustus 2014.

Hasil penelitian menyimpulkan bahwa: 1) Pelaksanaan dimensi religius melalui pembiasaan shalat lima waktu dan pembacaan al-qur'an baru dapat dilaksanakan oleh para siswa dalam kehidupan sebesar 36,82 \%,2) dari seluruh sekolah yang menjadi responden dalam penelitian ini, mayoritas belum dapat melaksanakan proses pendidikan karakter untuk dimensi religus dengan metode pembiasaan, 3) setelah dilakukan treatment metode pembiasaan, pelaksanaan shalat lima waktu dan pembacaan ayat-ayat al-qur'an mengalami peningkatan yang cukup signifikan; dari $36,82 \%$ menjadi $57,13 \%$, walaupun pelaksanaan shalat lima waktu belum dapat dilaksanaan tepat waktu oleh para siswa.

Kata Kunci: Pendidikan Karakter, Kegiatan Religi

\section{A. PENDAHULUAN}

1. Latar Belakang

$\begin{array}{lcr}\text { Hampir } & \text { setiap } & \text { saat kita } \\ \text { memonton } & \text { televisi } & \text { seringkali } \\ \text { disuguhi } & \text { tindakan } & \text { kekerasan, } \\ \text { tawuran, } & \text { dan } & \text { tindakan }\end{array}$

ketidakjujuran yang dilakukan oleh rakyat kecil sampai para pejabat. Kejadian ini menjadi indikasi kuat mengenai mulai hilangnya nilainilai luhur yang melekat pada bangsa Indonesia, seperti

361 Penerapan Teori Pembiasaan Dalam Pembentukan Karakter Religius di Tingkat Sekolah 
kejujuran, kesantunan, dan kemampuan membuat keputusan kebersamaan cukup menjadi justru tidak banyak digunakan, keprihatinan bersama. Oleh karena itu, harus ada usaha untuk menjadikan nilai-nilai itu kembali menjadi karakter luhur bangsa yang dibanggakan di hadapan bangsa lain. Salah satu upaya ke arah itu adalah perbaikan sistem pendidikan yang dititikberatkan pada pendidikan karakter. Pendidikan karakter menjadi salah satu solusi alternatif bagi upaya pemecahan masalah yang berhubungan dengan dekadensi moral yang sedang terjadi. Hal senada dengan visi depdiknas 2014 yang dirancang oleh Tim Pendidikan Karakter Kemendiknas Pada kenyataannya, visi depdiknas 2014 ini sepertinya belum dapat terealisir dengan maksimal. Hal ini diperkuat oleh hasil penelitian Zuhdi yang menyatakan bahwa; (1) konteks institusional sekolah masih belum secara optimal mendukung pelaksanaan pendidikan karakter; (2) strategi in doktrinasi masih digunakan meskipun porsinya tidak terlalu besar, kadar pemberian teladan masih perlu ditambah; fasilitasi nilai yang sangat sesuai untuk melatih 
bangun yang baik meliputi, tahapan-tahapan

terukur,setidaknya mengacu

kepada konsep kehidupan yang ingin diwujudkan:cerdas-modernreligius.

2. Identifikasi

Berdasarkan latar belakang di atas, maka dapat diidentifikasi permasalahan berikut:

a. Terjadinya degradasi moral yang terjadi dimasyarakat baik dari tingkat bawah sampai di tingkat atas yang diindikasikan dengan sering terjadinya kekerasan, tawuran, dan tindakan ketidakjujuran.

b. Belum terealisisasinya visi depdiknas 2014 secara baik

c. Belum adanya model khusus dalam pendidikan karakter yang efektif.

3. Rumusan Masalah

Berdasarkan identifikasi di atas, maka dapat dirumuskan masalah untuk mengetahui 1) sejauhmana penerapan pendidikan karakter religi melalui teori pembiasaan di Sekolah Dasar Negeri yang ada di wilayah Kota Tangerang Selatan, 2) sejauhmana pembiasan siswa dalam melaksanakan shalat lima waktu dan pembacaan ayat-ayat al-qur'an di Sekolah Dasar Negeri yang ada di wilayah Kota Tangerang Selatan

4. Tujuan dan Manfaat

Penelitian ini bertujuan untuk mengetahui: 1) penerapan pendidikan karakter religi melalui teori pembiasaan di Sekolah Dasar Negeri yang ada di wilayah Kota Tangerang Selatan, 2) pembiasan siswa dalam melaksanakan shalat lima waktu dan pembacaan ayatayat al-qur'an di Sekolah Dasar Negeri yang ada di wilayah Kota Tangerang Selatan

\section{B. HASIL DAN PEMBAHASAN}

\section{Kajian Teori}

a. Pengertian Pendidikan Karakter

Ekowarni menyatakan bahwa karakter merupakan nilai dasar prilaku yang menjadi acuan tata nilai interaksi antara manusia. Secara universal berbagai karakter dirumuskan sebagai nilai hidup bersama berdasarkan atas pilar: kedamaian, menghargai, kerjasama, kebebasan, kebahagiaan, kejujuran, kerendahan hati, kasih sayang, tanggung jawab, kesederhanaan, tolerensi dan persatuan. (Ekowarni, 2010)

$$
\text { Karakter }
$$

(character)

mengacu pada serangkaian sikap 
(attitudes), perilaku (behaviors), motivasi (motivations), dan keterampilan (skills). Karakter meliputi sikap seperti keinginan untuk melakukan hal yang terbaik, kapasitas intelektual seperti berpikir kritis dan alasan moral, perilaku jujur dan bertanggungjawab, mempertahankan prinsip-prinsip moral dalam situasi penuh ketidakadilan, kecakapan interpersonal dan emosional yang memungkinkan seseorang berinteraksi secara efektif dalam berbagai situasi, dan komitmen untuk berkontribusi dengan komunitas dan masyarakatnya. Karakteristik adalah realisasi perkembangan positif sebagai individu (intelektual social, emosional, dan etika). Individu yang berkarakter baik adalah seseorang yang berusaha melakukan hal yang terbaik (Battishtich, 2007).

$$
\text { Pendidikan karakter }
$$

dimaknai sebagai pendidikan yang mengembangkan nilai-nilai karakter peserta didik sehingga mereka memiliki nilai dan karakter sebagai karakter dirinya, menerapkan nilai-nilai tersebut dalam kehidupan dirinya, sebagai anggota masyarakat dan warga negara yang religius, nasionalis, produktif dan kreatif. Dengan demikian, pendidikan karakter adalah segala upaya yang dilakukan guru, yang mampu mempengaruhi karakter peserta didik. Tugas guru adalah membentuk karakter peserta didik yang mencakup keteladanan, perilaku guru, cara guru menyampaikan, dan bagaimana bertoleransi. (Zubaiedi, 2011: 14)

$$
\text { Pendidikan }
$$

karakter merupakan pendidikan budi pekerti plus, yaitu yang melibatkan aspek pengetahuan (cognitive), perasaan (feeling), dan tindakan (action). Tanpa ketiga aspek ini, pendidikan karakter tidak akan efektif, jadi yang diperlukan dalam pendidikan karakter tidak cukup dengan pengetahuan lantas melakukan tindakan yang sesuai dengan pengetahuan saja. Hal ini karena pendidikan karakter terkait erat dengan nilai dan norma. Oleh karena itu, harus juga melibatkan perasaan. (Akhmad Muhaimin Azzet, 2011: 27) 
Pendidikan karakter tidak sekadar mengajarkan mana yang benar dan mana yang salah kepada anak, tetapi lebih dari itu pendidikan karakter menanamkan kebiasaan (habituation) tentang yang baik sehingga siswa paham, mampu merasakan, dan mau melakukan yang baik. Pendidikan karakter ini membawa misi yang sama dengan pendidikan akhlak atau pendidikan moral.

Sementara itu, Zuchdi mengatakan bahwa ada empat hal dalam rangka penanaman nilai yang bermuara pada terbentuknya karakter (akhlak) mulia, yaitu: inkulkasi nilai, keteladanan nilai, fasilitasi, dan pengembangan keterampilan akademik dan sosial. Ditambahkan pula bahwa untuk ketercapaian program pendidikan nilai atau pembinaan karakter perlu diikuti oleh adanya evaluasi nilai. Evaluasi harus dilakukan secara akurat dengan pengamatan yang relatif lama dan secara terus-menerut. Dengan memadukan berbagai metode dan strategi seperti tersebut dalam pembelajaran pendidikan agama di sekolah, karakter siswa dapat dibina dan diupayakan sehingga siswa menjadi berkarakter seperti yang diharapkan.(Zuchdi, 2008)

b. Pengertian Kegiatan Religi

Pendidikan karakter siswa di sekolah merupakan upaya yang dilakukan oleh sekolah dalam rangka pembentukan karakter siswa. Terkait dengan sekolah, sekarang sedang digalakkan pembentukan kultur sekolah. Salah satu kultur yang dipilih sekolah adalah kultur akhlak mulia.

Kirschenbaum seperti yang dikutif Marzuki mengatakan bahwa ada lima metode yang bisa meningkatkan nilai dan moralitas (karakter/akhlak mulia) di sekolah, yaitu: 1) inculcating values and morality (penanaman nilai-nilai dan moralitas); 2) modeling values and morality (pemodelan nilai-nilai dan moralitas); 3) facilitating values and morality (memfasilitasi nilainilai dan moralitas); 4) skills for value development and moral literacy (ketrampilan untuk pengembangan nilai dan literasi moral; dan 5) developing a values education program (mengembangkan program 
pendidikan nilai). (Marzuki el al, 2011)

Apabila mengacu pada visi Depdikbud 2014, sangatlah wajar apabila semua sekolah dapat mengaplikasikan visi tersebut dengan memasukan unsur-unsur keagamaan dalam kurikulum tingkat satuan pendidikan di masing-masing sekolah. Kegiatan-kegiatan keagamaan tersebut harus tercantum juga dalam visi, misi dan tujuan sekolah. Selama ini kegiatan keagamaan (religi) ini hanya baru dilaksanakan oleh guru agama pada saat-saat tertentu saja seperti memperingati hari-hari besar keagamaan. Sementara aktifitas religi keseharian belum dapat dilaksanakan secara terencana dan kontinu.

Kegiatan religi dalam penelitian ini terfokus pada dua kegiatan, yaitu: kegiatan shalat (baik fardlu maupun sunnah) dan membaca al-qur'an dan suratsurat pendek. Kedudukan shalat dalam agama Islam yang menempati posisi penting yang tidak dapat digantikan oleh ibadah apapun juga, shalat merupakan tiang agama yang menjadi pondasi dari keberagaam dan kepribadian seseorang. (AsSyiddieqy, 2001: 287). Dengan melaksanakan salat berjama'ah minimal Zuhur dan Ashar karena kedua waktu sholat ini masih dalam waktu pembelajaran, atau shalat Duha, siswa siswi dididik beradaptasi dengan lingkungan sosialnya, pada saat salat berjama'ah mereka dapat belajar bagaimana berkata yang baik, bersikap sopan dan santun, menghargai saudaranya semuslim, dan terjalinnya tali persaudaraaan. (Wawan Susetya, 2007)

c. Implikasi Shalat dan Membaca Al-Qur'an terhadap Pelakunya

Menurut al-qur'an iman itu merupakan nur (cahaya) dari Allah SWT yang diberikan kepada orang yang telah dibukkan dadanya (memperoleh hidayah-Nya) untuk memeluk Islam. Namun demikian, pada mulanya nur keimanan tersebut masih dalam keadaan lemah atau kecil, seperti halnya bayi yang baru dilahirkan. Sesuatu yang lemah atau kecil belumlah dapat memberikan manfaat.

Oleh sebab itu, agar iman menjadi kuat dan besar senantiasa bersemayam dalam 
hati sanubari, maka ia memerlukan pembinaan yang berkesinambungan. Menurut Syamninah Zaini (1991: 82-83), pembinaan keimanan ini bisa dilakukan dengan tiga hal, yaitu: 1) dengan menambah ilmi, 2) memperbanyak ibadah dan perbuatan baik, 3) dengan menjauhi larangan Allah dan Rosul-Nya.

Salah satu bentuk ibadah yang diwajibkan oleh Allah SWT dan sangat istimewa adalah shalat lima waktu dan membaca al-qur'an. Menurut Zenal Mutakin (1999: 51 - 56) ada beberapa faedah atau manfaat dari melaksanakan shalat, yaitu:1) Shalat menjaga kesucian jasmani dan rohani. Su'dan (1997: 63) menyatakan bahwa dari sudut ilmu kesehatan, shalat mempunyai peranan penting dalam menjaga kesehatan jasmani. Setiap gerakan dalah shalat dapat menyembuhkan penyakit, seperti: ematik, bawajir, lumbago, dan spondylosis (penyakit yang suka menyerang tulang belakang), 2) Shalat sebagai pembinaan ummat. Islam mendidik ummat bergaul dan bermasyarakat.
Dengan melaksanaakan shalat secara berjamaah (seperti shalat lima waktu, shalat jum'at, dll) bisa menumbuhkan solidaritas sosial yang kuat dan ajaran persamaan antar manusia, 3) Shalat menankan kedisiplinan.Disiplin artinya mentaati peraturan. Hidup manusia harus dengan aturan. Hidup tanpa aturan akan menjadi kacau, karena itu hidup ini harus dengan disiplin. Menurut Zakiah Daradjat ( 1996: 37) menyatakan bahwa dalam salah satu firman Allah menyatakan bahwa manusia akan suskses dan bahagia di dalam hidupnya apabila mereka telah hidup dengan disiplin yang tinggi dalam berbagai aspek kehidupannya.

Sementara itu, hikmah membaca al-qur'an salah satunya adalah dapat menjadi amal ibadah dan dapat menjadi obat bagi pembacanya, terutama obat batiniah yaitu memberikan ketenangan dalam hidupnya

d. Teori Pembiasaan

Penerapan pendidikan karakter di sekolah setidaknya dapat ditempuh melalui empat alternatif strategi secara terpadu. 
Pertama, mengintegrasikan konten pendidikan karakter yang telah dirumuskan kedalam seluruh mata pelajaran, yang mencakup pengembangan nilainilai pendidikan budaya dan karakter bangsa diintegrasikan kedalam setiap pokok bahasan dari setiap mata pelajaran. Kedua, mengintegrasikan pendidikan karakter kedalam kegiatan sehari-hari di sekolah, yang mencakup keteladanan dan kebiasan rutin. Ketiga, mengintegrasikan pendidikan karakter kedalam kegiatan yang diprogamkan atau direncanakan. Keempat, membangun komunikasi kerjasama antar sekolah dengan orang tua peserta didik. (Novan Ardi Wiyani, 2012:78).

Dari keempat strategi di
atas, faktor pembiasaan
merupakan faktor yang sangat
penting dalam pendidikan
karakter. Dari beberapa pendapat
ahli dikatakan bahwa karakter
diidentikkan dengan akhlak.
Akhlak dapat dibentuk dengan
metode pembiasaan dan
penumbuhan kesadaran dalam
diri individu, meskipun pada
awalnya anak didik menolak atau

terpakasa melakukan suatu perbuatan atau akhlak yang baik, tetapi setelah lama dipraktekan, secara terus menerus dibiasakan dan dengan memahami arti penting tentang ibadah yang dilakukannya, maka akan menjadi sebuah karakter yang baik yang terpatri dalam dirinya. (Zaitun dan Siti Habibah, 2013).

Teori Pavlov menyatakan bahwa untuk menimbulkan atau memunculkan reaksi yang diinginkan yang disebut respon, maka perlu adanya stimulus yang dilakukan secara berulang-ulang sehingga disebut dengan pembiasaan. Dengan pemberian stimulus yang dibiasakan, maka akan menimbulkan respons yang dibiasakan. Sementara itu, Thorndike menyebutkan bahwa untuk memperoleh hasil yang baik maka kita memerlukan latihan. Latihan yang dimaksud ialah latihan yang dilakukan secara berulang-ulang dengan urutan yang benar dan secara teratur. Teori ini merujuk kepada system "coba-coba", yaitu suatu kegiatan yang bila kita gagal dalam melakukannya, maka kita harus terus mencoba hingga 
akhirnya berhasil. (Abdul Choer, 2009).

Nilai-nilai karakter penting diwujudkan dalam penerapan program pembiasaan. Nilai-nilai ini-lah nantinya sebagai output dari segala pelaksanaan pembelajaran dan budaya sekolah. Nilai-nilai tersebut, meliputi komponen pengetahuan, kesadaran atau kemauan, tindakan untuk melaksanakan nilai-nilai tersebut, baik untuk Tuhan Yang Maha Esa, diri sendiri, sesama, lingkungan, maupun kebangsaan sehingga menjadi manusia insan kamil. Usaha yang dapat dilakukan dalam rangka mem-bangun karakter bangsa adalah melalui penguatan budaya bangsa, aktualisasi nilai-nilai luhur Pancasila, impelementasi ajaranajaran agama dalam kehidupan sehari-hari, keteladanan dari semua kompo-nen bangsa, dan melalui pendidikan baik formal, informal, maupun non formal.

Salat dilakukan 5 kali sehari semalam ialah membiasakan umat manusia untuk hidup bersih dengan simbol wudhu, disiplin waktu dengan ditandai azan disetiap waktu salat, bertanggung jawab dengan simbol pengakuan di dalam bacaan doa iftitah "sesungguhnya salatku, ibadahku, hidup dan matiku untuk Allah", doa ini memberikan isyarat berupa tanggung jawab atas anugrah yang Allah telah berikan.

\section{Metode Penelitian}

Penelitian ini merupakan bagian dari penelitian riset dan pengembangan (Research and Development) yang dilaksanakan di beberapa Sekolah Dasar di Kota Tangerang Selatan dengan menerapkan pendidikan karakter melalui kegiatan religi. Penelitian ini dilaksanakan di Kota Tangerang Selatan. Waktu penelitian selama 6 bulan, yaitu bulan April - Agustus 2014

Subjek penelitian ini adalah 3 sekolah dengan 6 kelas Sekolah Dasar Negeri di Kota Tangerang Selatan yang berada di tiga kecamatan yang sudah menerapkan pembinaan karakter berbasis religi yang memiliki kualitas yang cukup baik.

Teknik pengumpulan data yang digunakan dalam penelitian ini adalah Focus Group Discussion (FGD), observasi, wawancara, dan dokumentasi. Untuk mendapatkan 
ISSN : 0852-1190

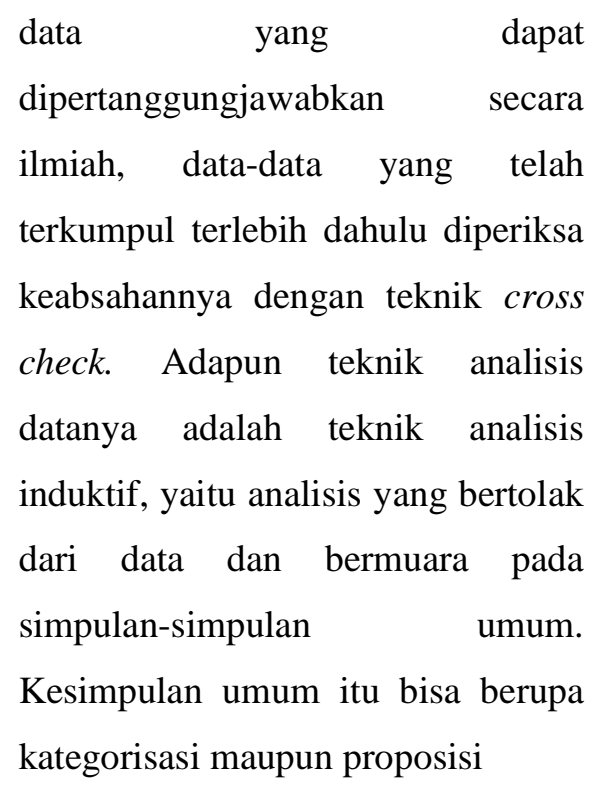

\section{Pembahasan}

a. Analisis Temuan

Hasil analisis statistik menyatakan: 1) untuk dimensi religius, pelaksanaan pendidikan karakter yang dilakukan oleh pihak sekolah diperoleh skor sebesar 55,3 $\%$, sementara untuk pelaksanaan pendidikan karakter yang dilakukan oleh siswa sendiri hanya $33 \%$ diimplementasikan dalam kehidupannya, 2) pelaksanaan dimensi religius melalui pembiasaan shalat lima waktu dan pembacaan alqur'an baru dapat dilaksanakan oleh para siswa dalam kehidupan seharihari sebesar $36,82 \%$, 3) dari seluruh sekolah yang menjadi responden dalam penelitian ini, mayoritas belum dapat melaksanakan proses pendidikan karakter untuk dimensi religus dengan metode pembiasaan.
Edutech, Tahun 13, Vol.1, No.3, Oktober 2014

Hasil wawancara dan angket isian dengan guru menyatakan bahwa pelaksanaan pendidikan karakter dengan metode pembiasaan dalam kegiatan religi dalam hal ini pelakasanaan shalat lima waktu dan shalat sunnah serta pembacaan alqur'an belum dapat dilaksanakan secara rutin dan terprogram, salah satu sebabnya adalah: 1) belum adanya buku panduan yang baku sebagai pedoman pelaksanaan, 2) fasilitas sekolah yang masih terbatas dan kurang memadai, dan 3) kurang sinergisnya kegiatan religi ini dengan program sekolah secara keseluruhan.

Hasil isian angket dari orang tua/wali murid menyebutkan bahwa sebelum dilakukan treatment metode pembiasaan pelaksanaan shalat lima waktu dan pembacaan ayat-ayat alqur'an, mayoritas siswa kurang peduli terhadap pelaksanaan shalat lima waktu apalagi untuk shalat tepat waktu, oleh karena itu tingkat kedisiplinan siswapun sangat rendah. Selain itu, rutinitas pembacaan ayat-ayat alqur'an pun belum dapat dilaksanakan secara baik. Setelah dilakukan treatment metode pembiasaan, pelaksanaan shalat lima waktu dan pembacaan ayat-ayat al-qur'an mengalami 
peningkatan yang cukup signifikan; waktu belum dapat dilaksanaan tepat dari $36,82 \%$ menjadi $57,13 \%$, waktu walaupun pelaksanaan shalat lima

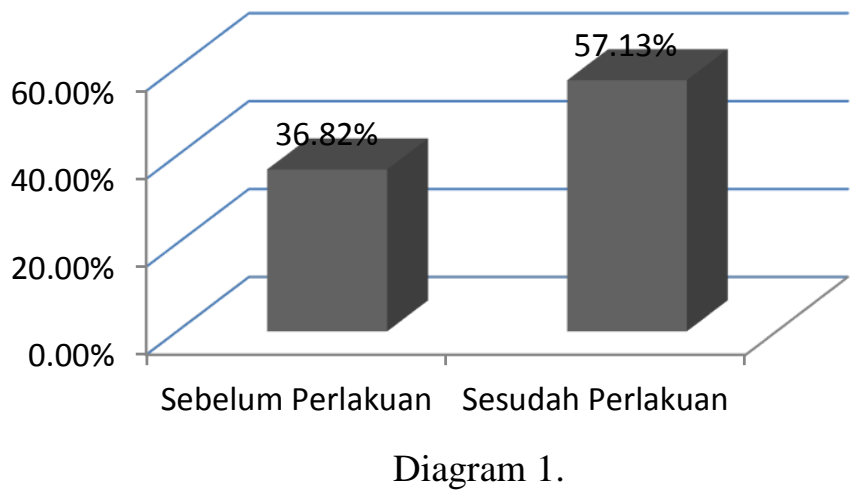

Metode pembiasaan, pelaksanaan shalat lima waktu dan pembacaan ayat-ayat al-quran

b. Analisis Kajian

Pada era globalisasi persoalan karakter menjadi sorotan tajam masyarakat dalam sistem pendidikan. Persoalan yang muncul seperti kekerasan dan kerusuhan, kejahatan seksual, penuturan bahasa yang buruk mengikis masyarakat Indonesia yang terbiasa santun dalam berperilaku serta bersikap toleran dan bergotong royong. Sistem pendidikan tanpa masuknya pembelajaran budi pekerti dan akhlak mulia, para lulusannya hanya mampu memiliki kompetensi akademik saja, tetapi tidak memiliki kompe-tensi kemanusiaan dan kompetensi sosial.

Karekter identik dengan akhlak. Akhlak merupakan karakter-karakter baik yang sudah terpatri dalam diri seseorang. Untuk menjadi sebuah karakter atau akhlak, maka diperlukan pelatihan-pelatihan secara rutin dan terbiasakan. Teori Pavlov dan Thorndike menyebutkan bahwa pembiasaan bisa mendapatkan hasil yang baik dari sebuah aktifitas diperlukan latihan yang berulang-ulang dan pembiasaan sehingga menjadi sebuah karakter.

Dari hasil penelitian yang dilakukan, proses pendidikan karakter religi dengan memakai metode pembiasan telah dapat meningkatkan aktifitas siswa dalam melaksanakan shalat lima waktu dan pembacaan ayat-ayat al-qur'an serta dapat meningkatkan karakter yang baik siswa dalam kehidupan seharihari. Walaupun disadari bahwa 
ISSN : 0852-1190

keberhasilan teori ini tidak bisa dilepaskan dari peran serta guru dan orang tua/wali murid di rumah.

\section{SIMPULAN}

Hasil uji statistik dan wawancara dengan Kepala Sekolah dapat diambil kesimpulan sementara sebagai berikut:

1. Penerapan pendidikan karakter religi di sekolah yang menjadi sampel penelitian belum terlaksana dengan baik. Hal ini diindikasikan dengan belum adanya program dan buku panduan dalam kegiatan tersebut.

2. Masih rendahnya pelaksanaan shalat lima waktu dan pembacaan ayatayat al-qur'an yang dilaksanakan para siswa baik di sekolah maupun di rumah.

3. Pelaksanaan kegiatan pendidikan karakter berbasis religi secara terprogram dan kontinu baru dilaksanakan sebagian kecil sekolah, dalam hal ini baru dilakukan oleh SDN Ciputat VI. Namun demikian, pada pelaksanaannya pendidikan karakter berbasis religi di SDN Ciputat VI pun belum dapat diukur keberhasilannya baik secara kualitatif maupun kuantitatif.

\section{DAFTAR PUSTAKA}

As-Syiddieqy, (2005) Hasbi, Pedoman Shalat, Jakarta: PT. Bulan Bintang, Azzet, Akhmad Muhaimin, (2011) Urgensi
Pendidikan
Karakter

Edutech, Tahun 13, Vol.1, No.3, Oktober 2014

Indonesia,Jogjakarta: Ar- Ruzz Media

Battistich, Victor. (2007). Character Education, Prevention, and Positif Youth Development. Illinois: University of Missouri, St Louis. (www.character.org/reports, diunduh tanggal 20 Peb 2011).

Chaer, Abdul. (2009) Psikolinguistik Kajian Teoretik. Jakarta: Rineka Cipta

Darajat, Zakiyah, Prof. Dr., (1996) Shalat Menjadikan Hidup Bermakna, Jakarta: Ruhama

Depdiknas RI. (2004). Pengembangan karakter Sekolah. Jakarta: Depdiknas RI.

Ekowarni, Endang, Pengembangan NilaiNilai Luhur Budi Pekerti sebagai karakter Bangsa, diaksek dari http://litbangkemdiknas.net/content/ ABSTRAK-JANUARI.pdf, tanggal 20 Peb 2011

Marzuki, Murdiono M., Samsuri, Jurnal Kependidikan, Volume 41, Nomor 1, Mei 2011, diakses dari http://litbangkemdiknas.net/content/ ABSTRAK-JANUARI.pdf, tanggal 20 Peb 2011

Su'dan, R.H., dr., (1997) Al-Qur'an dan Panduan Kesehatan Masyarakat, Yogjakarta: PT. Dana Primayana 
Susetya, Wawan,(2007) Sebuah Kerinduan

Salat Khusyuk, Yogyakarta: Tugu Publisher

Wiyani, Novan Ardi, (2012) Manajemen Pendidikan Karakter; Konsep dan Implementasinya di Sekolah, Yogyakarta, PT Pustaka Insan Madani

Zenal Mutakin, Tatan,(1999) Urgensi Shalat dalam Membentuk Sumber Daya Manusia yang Bekualitas, Skripsi, Jakarta: IAIN Syarif Hidayatullah Jakarta
Zaitun dan Siti Habibah, (2013) Jurnal Pendidikan Agama Islam - Ta'lim Vol 11 No. 2

Zaini, Syahminah, Drs., H.,(1991) Faedah Shalat bagi Kehidupan Orang Beriman, Jakarta: Kalam Mulia

Zuchdi, D. (2008). Humanisasi pendidikan: Menemukan kembali pendidikan yang manusiawi. Jakarta: PT. Bumi Aksara

Zubaiedi, (2011) Desain Pendidikan Karakter: Konsepsi dan Aplikasinya Dalam Lenbaga Pendidikan, Jakarta: Kharisma Putera Utama, 